\title{
The First Conspiracy the Secret Plot to Kill George Washington. By Brad Meltzer and Josh Mensch, New York, N.Y.: Flatiron Books, 2019.
}

Millard E. Moon Ed.D., Colonel (ret.)

U.S. Air Force Office of Special Investigations

Follow this and additional works at: https://digitalcommons.usf.edu/jss

pp. 170-174

\section{Recommended Citation}

Moon, Millard E. Ed.D., Colonel (ret.). "The First Conspiracy the Secret Plot to Kill George Washington. By Brad Meltzer and Josh Mensch, New York, N.Y.: Flatiron Books, 2019.." Journal of Strategic Security 12, no. 3 (2019) : 170-174.

DOI: https://doi.org/10.5038/1944-0472.12.3.1767

Available at: https://digitalcommons.usf.edu/jss/vol12/iss3/5

This Book Review is brought to you for free and open access by the Open Access Journals at Digital Commons @ University of South Florida. It has been accepted for inclusion in Journal of Strategic Security by an authorized editor of Digital Commons @ University of South Florida. For more information, please contact digitalcommons@usf.edu. 
The First Conspiracy the Secret Plot to Kill George Washington. By Brad Meltzer and Josh Mensch, New York, N.Y.: Flatiron Books, 2019. 


\section{The First Conspiracy the Secret Plot to Kill George} Washington. By Brad Meltzer and Josh Mensch, New York, N.Y.: Flatiron Books, 2019. ISBN: 978-1-250-13033-4, ISBN: 978-1-250-23122-2 (signed edition), ISBN: 978-1-250-13034-1 9 (ebook), Author's Note, Notes on text, Cast of Characters, Notes, Selected Bibliography, Index, Pp. 413, \$29.99.

Brad Meltzer is a well-known author who has had a number of best-selling fiction books published. He also hosts two History Channel TV shows, Brad Metzer's Decoded, and Brad Meltzer's Lost History. He is credited with helping to locate the missing 9/11 flag, which firefighters raised at Ground Zero. Josh Mensch is a writer and documentary television producer focusing on American history and culture. He has produced, written, and directed series for a number of networks, including PBS, National Geographic, A\&E, Discovery, and was the showrunner on Brad Meltzer's Lost History. The two authors' research led them to consult Pulitzer Prize winning historian Joseph J. Ellis, as well as historian and Washington expert, Barnet Schecter, among others.

This work reads like a history of the early stages of the American Revolution, plus the beginnings of our nation's intelligence and counterintelligence services, all wrapped in a mystery thriller. In 1776 General George Washington was desperately trying to organize an army mainly composed of militia and untrained volunteers. The British were awaiting reinforcements of troops and naval power while the Continental troops under Washington were working on defenses for New York City, a nearly impossible task.

To add to the huge task of defending an area with water on three sides and no Continental Navy to oppose England's well-developed navy, as well as untrained troops facing what was arguably the best trained army in the world, there were constantly shifting loyalties among a large number of civilians and even within the ranks of the military. Much of the history presented in general school courses skims over the story of the supporters of England's Monarch. These supporters of the Crown, to whom most had sworn allegiance, became known as Loyalists and included many officials appointed to high office in the American Colonies. The Governor of the New York Colony, William Tryon, fled to a British naval vessel and 
directed a large covert operation against Washington and his forces. Tryon enlisted the services of the Mayor of New York City, David Mathews, whom he had appointed in February of 1776. This ongoing operation was conducted for a time with little or no interference from Washington's army.

Washington had served as an officer with British General Braddock in the French and Indian War, but still had a lot to learn about commanding an army. While the Continental forces prevailed in Boston for a time in 1775, one unexpected incident highlighted the need for both an intelligence and counterintelligence force. A baker who was renowned among both British and Continental forces for his tasty biscuits approached General Nathaniel Greene with a letter a former girlfriend had asked him to pass to the British forces. General Greene took the baker, Godfrey

Wentwood, and the letter to General Washington. The letter was in code and since there were no cryptographers to decode it, Washington had to hire two teams in the Cambridge area.

Working independently, they came up with almost identical translations. The letter detailed military information on the Continental troops, defenses, and other critical information. The letter was intended for British General Thomas Gage. The baker's former girlfriend was taken into custody and after a lengthy interrogation agreed to tell Washington the name of the man who had given it to her to deliver. She was the man's Mistress, and his name was Doctor Benjamin Church. Church was a trusted patriot and the first Surgeon-General of the Continental Army.

This focused attention on the need for intelligence and counterintelligence operatives. There were many spies on both sides, some of whom changed allegiance from time to time. At one point, Washington decided to have General Charles Lee address the espionage problems in New York. General Lee reported clandestine activity with a focus on Governor Tryon operating a spy ring from the British ship where he was housed. This was expanded upon by Lee's successor, General William Alexander, known as Lord Stirling, who gave an alarming report that 50 to 60 of the soldiers serving in the army had been bought by operatives of Tryon. When Washington entered New York City, he had a special unit of bodyguards known as the Life Guard. Their commander, Captain 
Caleb Gibbs, made certain at least two soldiers of the Life Guards were always on duty at the front of the house where General Washington lived, and a security detail of Life Guards were always with him in any movement. Captain Gibbs scheduled shifts, planned movements, and oversaw the housekeeper, Mary Smith.

Drunkenness, disease, and violence plagued the troops and taxed their commander. Even some soldiers of the Life Guards were not immune to violations of discipline. The authors do an excellent job of describing conditions and subplots which led to uncovering a plot to murder Washington, using members of his own elite Life Guards. A former British soldier, now a member of the Life Guards, Sergeant Thomas Hickey, and another Life Guard member, Thomas Lynch, were jailed for the relatively minor offense of carrying counterfeit money. They were confined with one Issac Ketcham, who had been imprisoned in connection with a counterfeiting operation based on Long island. When Ketchum realized he was considered a major offender, he attempted to win favor by testifying before Congress and implicating the Life Guard members in a Loyalist plot to kill Washington. A Committee on Conspiracies, consisting of three members, John Jay, Gouverneur Morris, and Phillip Livingston, had been appointed to conduct investigations into clandestine operations. They received more definite information from William Leary, a foremen at the Ringwood Ironworks, who had been approached by former co-workers to join the Loyalists and who turned over one of these men to the Committee.

John Jay, best known for his public service in law enforcement and as Chief Justice of the United States Supreme Court, is recognized by counterintelligence professionals as the Father of Counterintelligence. Jay headed this and other investigations. As the authors point out, there is a room in the Headquarters of the Central Intelligence

Agency named in his honor. Although not mentioned in this book, there is a room named for George Washington as the Father of Intelligence, and one named for Benjamin Franklin as the Father of Covert Operations.

Much of the information concerning the plot to kill or kidnap Washington has either remained hidden or been destroyed and lost to history. These early spymasters knew how to maintain operational security. In addition to the obvious concerns, there would have been a major adverse impact on 
the troops and the colonies which would eventually form the United States. We know as a result of the work by John Jay and his other committee members, a number of Loyalist spies and operatives were arrested and imprisoned.

The details of the plots, subplots, investigations, and participants are detailed by the authors as far as their research could reveal information. Although David Mathews was among them, he survived the war and died in 180o. A small park in New York City bears his name as well as another totally unrelated individual's name. Mathews claimed after the war that the plan had been to kidnap Washington rather than to kill him. Tryon escaped and became a British Major General who fell into controversy over alleged war crimes against civilians. He died some five years after the war ended. Strange as it may seem, a number of streets, parks, and at least one major museum bear his name and are scattered around North Carolina, and New York State.

On June 28, 1776, having been convicted of treason, Thomas Hickey was marched to a gallows with all units of the Continental Army in New York drawn up in a square. Hickey was hanged for treason. There is little or no information about what, if anything, happened to others involved in the plot. Washington's housekeeper, Mary Smith disappeared overnight. One of the other Life Guards was alleged to be the ringleader of the plot, but even though a number of Life Guards were implicated, only Hickey was publicly identified and executed.

Meltzer and Mensch have written a very readable and well documented historical account which covers the beginnings of our country's intelligence and counterintelligence history. They freely admit that some things cannot be documented by anyone today. Even some historians are only aware of the bare outlines of this story. In order to make the complex story flow clearly, the authors changed the name of a relatively minor player named William Forbes to Farley so as to avoid confusion with a conspirator with a much bigger role named Gilbert Forbes. This is clearly explained in the section on Cast of Characters.

If George Washington had been kidnapped or killed most historians would agree that the United States might not have become a nation. If Washington, John Jay, and others had not realized the absolute need for a 
fully developed intelligence and counterintelligence structure for our country, we probably would not have remained a free nation. Many professionals in this area fully appreciate the shadow world our founding fathers created, not for personal glory, but to serve the nation. They will also understand and appreciate the comment by historian Joseph J. Ellis, quoted in the Author's Note page at the very beginning of the book. Concerning George Washington and his inner circle, Ellis said, "You can find the exact number of slaves at Mount Vernon, but you will never find all his spies. By its nature, this is something that will always be elusive."

Millard E. Moon, Ed.D.., Colonel (ret), U.S. Air Force Office of Special Investigations 